\title{
Vision 2025 and the Bible translation movement
}

\begin{tabular}{|c|c|}
\hline $\begin{array}{l}\text { Authors: } \\
\text { Kirk J. Franklin }{ }^{1}\end{array}$ & Niemandt $^{1}$ \\
\hline \multicolumn{2}{|c|}{$\begin{array}{l}\text { Affiliations: } \\
{ }^{1} \text { Department of Science of } \\
\text { Religion and Missiology, } \\
\text { University of Pretoria, } \\
\text { South Africa }\end{array}$} \\
\hline \multicolumn{2}{|c|}{$\begin{array}{l}\text { Note: } \\
\text { Submitted and accepted as } \\
\text { part of the requirements for } \\
\text { the MA (Theology) degree } \\
\text { in September 2012, the } \\
\text { Department of Science of } \\
\text { Religion and Missiology, } \\
\text { Faculty of Theology, } \\
\text { University of Pretoria, under } \\
\text { the guidance of Prof C.J.P. } \\
\text { (Nelus) Niemandt. }\end{array}$} \\
\hline \multicolumn{2}{|c|}{$\begin{array}{l}\text { Correspondence to: } \\
\text { Nelus Niemandt }\end{array}$} \\
\hline \multicolumn{2}{|c|}{$\begin{array}{l}\text { Email: } \\
\text { nelus.niemandt@up.ac.za }\end{array}$} \\
\hline \multicolumn{2}{|c|}{$\begin{array}{l}\text { Postal address: } \\
\text { Private Bag X20, Hatfield, } \\
\text { Pretoria } 0028 \text {, South Africa }\end{array}$} \\
\hline \multicolumn{2}{|c|}{$\begin{array}{l}\text { Received: } 12 \text { Sept. } 2012 \\
\text { Accepted: } 16 \text { Mar. } 2013 \\
\text { Published: } 15 \text { May } 2013\end{array}$} \\
\hline \multicolumn{2}{|c|}{$\begin{array}{l}\text { How to cite this article: } \\
\text { Franklin, K.J. \& Niemandt, } \\
\text { C.J.P., 2013, 'Vision } 2025 \\
\text { and the Bible translation } \\
\text { movement', HTS Teologiese } \\
\text { Studies/Theological Studies } \\
69(1), \text { Art. \#1332, } 8 \text { pages. } \\
\text { http://dx.doi.org/10.4102/ } \\
\text { hts.v69i1.1332 }\end{array}$} \\
\hline \multicolumn{2}{|c|}{$\begin{array}{l}\text { Copyright: } \\
\text { C 2013. The Authors. } \\
\text { Licensee: AOSIS } \\
\text { OpenJournals. This work } \\
\text { is licensed under the } \\
\text { Creative Commons } \\
\text { Attribution License. }\end{array}$} \\
\hline \multicolumn{2}{|l|}{ Read online: } \\
\hline ary & $\begin{array}{l}\text { Scan this QR } \\
\text { code with your } \\
\text { smart phone or } \\
\text { mobile device } \\
\text { to read online. }\end{array}$ \\
\hline
\end{tabular}

Complex questions have arisen about how Christian mission agencies function within a globalised context. The changing context has impacted on how the missio Dei has been worked out within these agencies and this has had implications of a theological and missiological nature in particular as to how the agencies have interacted with the church worldwide. This has lead to new paradigms of how mission is conceptualised. The growth of the church worldwide in newer soil has forced mission agencies such as the Wycliffe Global Alliance (WGA) to reevaluate their place in the world. It has been assumed that as resources have decreased from parts of the world where the WGA has had its traditional roots, there are missiological factors in determining how this impacts on the WGA. There are many missiological implications for the WGA that come from influences in church history on the importance of the translatability of the gospel especially in the context of Bible translation. These have impacted the WGA's understanding of itself and in particular of how it has interpreted and reinterpreted its Vision 2025. When the missio Dei converges with outcomes of globalisation there are numerous implications for an agency such as the WGA. Consequently, the article concludes that none of these matters can be ignored. Instead they must be explored and lessons learnt from them that can be passed along to others in similar situations.

\section{Introduction}

This research focuses on one organisation within the global Bible translation movement - the Wycliffe Global Alliance (WGA). The research explores these areas: (1) the historical theological influences on the WGA; (2) the missiological significance of the translatability of the Bible (with the outcome of Bible translation being a core objective of the WGA) and (3) the missiologicaltheological implications of the WGA's Vision 2025. The aim is to determine how the WGA has responded to these areas in light of the changing global church and mission context.

\section{Implications for the changing demographics of the church}

Globalisation affects the policies and practices of global mission agencies such as the WGA. This requires a re-evaluation of the strategies and objectives of global mission agencies, especially in light of the growth of the church in the global South and East (sub-Saharan Africa, Latin America, the Caribbean, Asia and the Pacific Islands). Philip Jenkins (2002:3) stated that by the end of the 20th century, the vast majority of Christians lived outside of Western nations of Europe and North America, as well as Australia and New Zealand. Jenkins (2002:3) calls this shift in church population, the passing of 'the era of Western Christianity.' Christian leadership coming from the global South and East is well underway and the new centre of influence has many implications. Mission scholars note, for example, that 'global plans [for mission] are increasingly initiated and led by Christians of the Global South' (Barrett, Johnson \& Crossing 2008:28).

Despite this trend, mission endeavours are still largely influenced and resourced by churches in Western nations. For example, mission researcher Patrick Johnstone (2011:64) noted that by the year 2000 there were 3000 cross-cultural mission agencies and the ten largest interdenominational and international agencies - which had between them more than 50000 missionaries - were all from the West, at least in their origins or the locations of their headquarters. The salient point is that mission agencies located in Western nations continue to have the primary influence upon cross-cultural mission strategy and methodology.

\section{Early theological influences on Wycliffe Global Alliance}

Historically, the greatest theological influence upon the WGA rose from its roots in the evangelical soil of the United Sates of America (USA) in the early 20th century. This perspective shaped how its US supporters viewed the concept of the mission of God (missio Dei) and, in turn, this formed how the organisation understands the missio Dei. This issue is crucial because agencies formed in this evangelical context are largely pragmatic and tend to view mission as 'almost exclusively [about the] various tasks the church is doing' (Tennent 2010:54). 
Before proceeding further, it is important to clarify the development of the WGA: in 1942, William Cameron Townsend formed Wycliffe Bible Translators (eight years earlier he had formed the Summer Institute of Linguistics, now called SIL International). Wycliffe was primarily an American organisation until 1980 when an international body was formed called Wycliffe Bible Translators International (WBTI) as an outgrowth of the US organisation. In 2011, the international body was renamed the Wycliffe Global Alliance (WGA).

\section{The influence of the Great Commission}

Since the WGA was first founded, its theological heritage has influenced its interpretation of Matthew 28:18-20 (and related texts in the Gospels and Acts). This text has often been cited exclusively by American evangelical mission agencies as the 'Great Commission'. However, Timothy Tennent (2010:127) observes that the Great Commission is 'frequently treated as an isolated pericope, separated from the rest of the gospel as well as the larger biblical context of the missio Dei.'

Some authors note that the Great Commission texts, when removed from their wider scriptural contexts, are 'unwittingly denuded ... of some of their power' (Klauber \& Manetsch 2008:177). Chris Wright (2006:35) offers a moderating perspective by stating that every generation, whether Christianised or not, needs to be disciple oriented because 'the Great Commission is an expanding and selfreplicating task, not a ticking clock for the end times.'

William Carey (1761-1834), often referred to as the 'father of the modern missionary movement', indirectly referenced Matthew 28:18-20 as the basis for his understanding of evangelism. He developed his view in his booklet, 'Enquiry into the obligation of Christians to use means for the conversion of heathens' (Carey 1792). His thesis was to determine whether:

the commission given by our Lord to His disciples [is] still binding on us; [to] consider the practicability of doing something more than is done; and [to] discuss the duty of Christians in general on this matter. (Hunt 2010:83)

Whilst Carey himself never used the term 'Great Commission', just 'commission', his conclusion was that Christians needed to work together to take the gospel to unevangelised people (or today what might be called 'unreached people groups'). At the time, Carey's booklet was a catalyst that motivated Christians in the USA and United Kingdom (UK) to become vigorous in their obedience to fulfil the Great Commission (Peskett \& Ramachandra 2003:174).

Consequently, a characteristic of many evangelicals has been to distinguish themselves as primarily responsible for completing the Great Commission (Gailey \& Culbertson 2007:14). Still others portray their involvement as 'affirming God's call to an accelerated harvest in Latin America, Africa,
Asia and Europe that reflects the fruit of those who went in previous generations' (Terry, Smith \& Anderson 1998:30).

\section{The influence of Bible institutes}

Townsend, Wycliffe's founder, grew up in the early 20th century when many Bible institutes and faith mission organisations in the USA were being formed (starting in the late 19th century). It was a happy 'marriage' between the two because 'the Bible institutes nurtured a unique spiritual vision, and the faith missions provided the outlet for putting that vision to the test' (Svelmoe 2008:18). Their devotion and zeal for evangelism followed the principles they interpreted in the Great Commission passages and this viewpoint greatly influenced Townsend as well. For example, when articulating his burden for the urgency of Bible translation, he told his colleagues of his:

real concern of hastening the return of our Lord and the coming of that Great Day when we can look out on the throng of the redeemed from every tribe and nation and language. (Hibberd 2007:68)

Evangelical fervour in the era of the WBT's formation destined Christians to see themselves as responsible for bringing the Great Commission to completion, or at least doing their part to accelerate the mission mandate. Evangelicals believed they played a critical role in achieving God's will.

The Bible institutes and mission organisations believed that the missionary personified 'a near legendary role' (Svelmoe 2008:18) in the evangelical movement's positive vision of itself. At the heart of this optimistic belief was the concept of a 'manifest destiny' that reached its zenith in 1880-1920. It went beyond the scope of the Great Commission and employed an Old Testament understanding of a 'chosen people'. David Bosch (1991) elaborates:

virtually every white nation regarded itself as being chosen for a particular destiny and as having a unique charisma ... . [Consequently] a specific nation would develop the conviction that they had an exceptional role to play in the advancement of the kingdom of God through the missionary enterprise. (p. 299)

\section{The influence of early 20th century optimism}

Another factor in mission expansion was the optimism of the early 20th century, as expressed by the Edinburgh Missionary Conference of 1910 where the delegates believed the world was quite easily winnable for Christ.

The lesson for us today is that whenever the church (and mission agencies) sounds exuberant or triumphant about the progress of the evangelisation of the world, it should provide a warning to cautiously examine and learn from the history of the missionary enterprise. In doing so, one notes that periods of expansion of the gospel and therefore the church are inevitably followed by times of recession. Andrew Walls (2002:1-2), for example in his analysis of church history, notes that it is a serial progression in terms of new people and regions adopting the Christian faith rather than one in which the church conquers and holds new territory. 


\section{Theological importance of language}

In the account of the day of Pentecost (Ac 2), Jews had gathered in Jerusalem from all over the world (15 regions and countries). The Holy Spirit settled on the disciples and miraculously empowered them to speak the languages of all who were represented. This happened so dramatically that many who were there acknowledged 'we hear them declaring the wonders of God in our own tongues!' (Ac 2:11). The event was God's initiative and it 'implied the reversal of the course of Babel' (Gn 11:1-9) because Babel symbolised 'the global rebellion against God' (Tennent 2010:412).

The event in Acts 2 demonstrates God's acceptance of everyone's language and how he uses each to bring an awareness of himself. As Tennent (2010:412) states, 'at Pentecost ... a small group of Jewish followers of Jesus are baptized [sic] into the reality of the infinite translatability of the gospel for every language and culture.' (Lesslie Newbigin (1989:185) adds, 'Pentecost is our biblical warrant for saying that God accepts language.' Furthermore, there is an eschatological fulfilment when God gathers people from every tribe, language and nation before his throne ( $\operatorname{Rv} 5: 9)$. It follows that the Pentecost event establishes the translatability of the gospel and the importance God places on the vernacular language as a primary means of communicating the truths of God.

The account of the day of Pentecost also reinforces how God's mission is dependent upon the Holy Spirit, regardless of any cultural, social, economic, political and linguistic barriers that exist. This action is not passive by the Spirit, but rather demonstrates how the Spirit empowers the people of God for an outward movement to the nations; and, as they do so, they establish the church wherever they gather.

\section{Historical importance of Bible translation}

The translatability of the gospel is the key to an appreciation of why the translation of the Bible into the languages of the world is important in the missio Dei. It illustrates the act of the incarnation because 'God chose translation as his mode of action for the salvation of humanity' (Walls 1996:26). As the Word became flesh (Jn 1:14), 'the translatability of the Bible rests on [this] prior act of translation' (Walls 1996:26). This concept of translatability is 'the ability of the gospel to be articulated, received, appropriated, and reproduced into a potentially infinite number of cultural contexts' (Tennent 2010:325).

Throughout the history of the church, Christians have viewed the translation of the Bible into the languages of the world as an indispensable foundation for the sustainable mission of God. This is not a simple task, as Walls warns, 'translation is the art of the impossible' due to the risky complexity of transmitting meaning from 'one linguistic medium to another' (1996:26).

If 1st-century Christians had only passed the gospel along to us today by means of the cultural grids that were unique to them, the Christian faith would have been robbed of the insights of various Christians since then, such as Europeans, Asians, Africans or Latin Americans. As Tennent states, 'we have gained more and more insights into the beauty and reality of Jesus Christ' (2010:336) for the very reason that Christians by and large have followed the 'mission by translation' option - with all of the pitfalls and dangers of mistranslations in mind.

\section{Bible translation has been important to the early church The importance of the Septuagint}

The activity of translating the Bible, or at least portions of it, started with the Septuagint, the ancient translation of the Hebrew Old Testament into Koine Greek. The work is thought to have commenced prior to $285 \mathrm{BCE}$. Eventually it were the Jews of the Diaspora living in Alexandria who:

had abandoned the language of their fathers [and thought] that the only way to preserve the religious legacy of their ancestors was to translate it into the foreign language that they use. (Marcos 2000:19)

These Jews were bilingual and their translation was to address the liturgical and educational needs of the Jews living in 'the Greek world with a high proportion of Greekspeaking Jews who did not know the original language of the scriptures' (Marcos 2000:20).

Once the Bible was translated, it was copied over and over by scribes and distributed widely around the Mediterranean area. It should be pointed out that the LXX was actually a 'collection of translations depending on the book [resulting in] a whole gamut of translation techniques which run from literal translation (including transliteration) to paraphrase' (Marcos 2000:23). It was from the Septuagint that Jesus quoted in the gospel accounts.

Those following traditional Judaism eventually abandoned the Septuagint and stated that the Torah could not be adapted into Greek. By then the Septuagint was largely in the hands of Hellenistic Gentile believers, where these scriptures enjoyed a new function, becoming 'an authoritative sourcebook for Greek Christians seeking to build a coherent world view' (Walls 1996:33).

\section{Jesus' teachings and Paul's writings}

The accounts about the life and teachings of Jesus were circulated orally from person to person. During 50-60 CE, the Apostle Paul's letters were either written in Koine Greek or dictated to scribes who transcribed them (Wegner 1999:207). Scribes recopied them by hand, making them more readily available and they were read in the meetings of the early church.

In the early church the use of the Bible was considered necessary for every Christian. The church fathers emphasised Bible reading, which in turn encouraged people to become literate. For those who were not literate, the Bible was read 
publicly because it was considered as essential for deepening the spiritual life of individual Christians and the church.

\section{Early influence of Bible translation}

Kwame Bediako (2004) describes the influence of Bible translation on the growth of the church:

Christianity among all religions, is the most culturally translatable, hence the most truly universal, being able to be at home in every cultural context without injury to its essential character. (p. 32)

Lamin Sanneh (2003:97) elaborates: the gospel is in fact a 'translated version of the message of Jesus, and that means Christianity is a translated religion without a revealed language.'

This comment provides an important theologicalmissiological justification for Bible translation that started with the incarnation. At that time God became human and 'divinity was translated into humanity, as though humanity was the receptor language' (Walls 1996:27). This 'translation' act enabled Christ to be born as a person in 1st-century Jewish Palestine. Through the continuing challenge of the Great Commission, people from all nations are to be made Christ's disciples. Each geographic and cultural context needs to be considered because the first divine act of translation into humanity ... gives rise to a constant succession of new translations' (Walls 1996:27).

\section{Bible translation since the 19th century}

Since the modern missionary movement of the past 200 years, a monumental effort has taken place in translation, so that currently there are over 2300 languages that have at least one book of the Bible.

\section{Impact on the African continent}

Sanneh (1989:209) explores the effects of Bible translation and the spread of the gospel over the past 200 years in Africa and notes that all African languages 'may confidently be adopted for God's word, a step that allows missionaries and local agents to collaborate, if sometimes unevenly, in the missio Dei.' The translatability of the Bible empowers people and societies to be better equipped through their vernaculars to deal with changes brought upon them by outside influences and adapt to their changing contexts. This is possible because 'translatability acquired a life of its own, which translators could not control' (Sanneh 1989:206).

The positive effect of Bible translation in the vernaculars of Africa is attributed to how the gospel is so readily translatable. This is because the message of the Bible demonstrates a 'refusal of a "sacred" language [and it] developed a "vernacular" faith' (Bediako 2004:32). Sanneh (2003:97) observes that 'without translation there would be no Christianity or Christians. Translation is the church's birthmark as well as its missionary benchmark: the church would be unrecognizable [sic] or unsustainable without it.'

\section{Impact upon cross-cultural mission}

The availability of vernacular scriptures has been the groundwork for effective cross-cultural mission since 'the complicated task of translating the Bible ... has sometimes been an outgrowth of mission activity [and] sometimes the entering wedge' (Smalley 1991:21). The spiritual understanding gained from the vernacular scriptures encourages harmony within the emerging Christian communities. Through reading and understanding the translated scripture, people are made aware of God and his desire to have a relationship with them. They can apply scripture to their daily life and, with training and study, do theology in their cultural contexts.

As a result of the extraordinary efforts of Christian linguists and translators, 'more people pray and worship in more languages in Christianity than in any other religion' (Sanneh 2003:69). A related benefit is that Christians have produced more grammars and dictionaries of the world's languages than any other cause (Sanneh 2003:69).

A primary concern of Bible translation is that it represents the language of the heart. This is the language that the majority of people in a given ethno-linguistic group most effectively communicate with on personal and deep spiritual matters. Bediako (2004:58) states, 'whenever Western missionaries ... made the Scriptures available to an African people in that people's own language, they weakened any Western bias in their presentation of the Gospel.' The consequence was that African Christians 'could truly claim they were hearing God speak to them in their own language' (Bediako 2004:58).

The late Eugene Nida (1914-2011) worked with other scholars and Bible translators to improve the theory and practice of Bible translation. He borrowed concepts from the fields of linguistics, cultural studies, communication sciences and psychology to develop a 'practical approach to translation that he called dynamic equivalence or functional equivalence, the goal of which was to make the translation clear and understandable as well as accurate' (Stine 2012:38). Nida's influence has been seen in most popular Bible translations in major as well as lesser known languages.

\section{The importance of literacy}

The twin effort accompanying Bible translation is literacy, which is built on the foundation of linguistics. These related fields have been greatly influenced by missionaries. During the centuries of upheaval and expansion of the church, missionaries 'became pioneers of linguistic development ... [and] the resulting literacy, however limited, produced social and cultural transformation' (Sanneh 2003:99).

One of the challenges for speakers of smaller languages is how literacy campaigns by governments and other institutions are 
conducted, especially if the national or regional languages are used. K. David Harrison (2007:148) warns, 'many small languages will vanish without ever having literate speakers [because] small languages are seldom included in national literacy campaigns.' An unfortunate consequence is that literacy in larger and or national languages often results in the abandonment of the smaller languages.

Not all societies are comfortable with reading and writing because of their oral traditions. It is therefore important that oral strategies to introduce the themes and stories of the Bible are documented and implemented for such societies. When this is the lead strategy, Jenkins notes, 'learning to read the text is a later, and not inevitable, phase of Christian development' (2006:31).

\section{Globalisation and mission}

Much has been written about the topic of globalisation because its effects, both positive and negative, are felt with great impact on every corner of the planet. Globalisation is defined as an:

increasing interconnectedness, so that events and developments in one part of the world are affected by, have to take account of, and also influence, in turn, other parts of the world. (Tiplady 2003:2)

The heart of globalisation is the spread of this economistic culture throughout the world and the attempt to secure dominance among all peoples everywhere' (Smith 2003:93). Some refer to this as 'global unification' through the 'unfettered expansion' of free market economies (Gaillardetz 2006:158).

Anthony Giddens has written much on the topic of globalisation and from his experience states that it 'not only pulls upwards, but also pushes downwards, creating new pressures for local autonomy' (2003:13). As a result 'local nationalisms spring up as a response to globalising tendencies, as the hold of older nation-states weakens' (Giddens 2003:13). Globalisation is therefore a factor behind the renewal of cultures and their traditions in various countries. However, one of the problems with globalisation is that it often leads to the destruction of local cultures and results in a widening gap in wealth and poverty. This creates an environment of winners and losers where a few quickly prosper but the majority are 'condemned to a life of misery and despair' (Giddens 2003:15). Globalisation brings social upheaval because of cultural and religious differences that defy integration. It spawns 'deep pluralism that often seems unbridgeable' and creates 'violent tribalism' along with religious fundamentalism (Gaillardetz 2006:158).

Whilst fundamentalism has always been a part of the Christian church, current world religions have 'fundamentalists' who are reacting to globalisation in various manners. Giddens (2003) defines fundamentalism as:

a return to basic scriptures or texts, supposed to be read in a literal manner [with] the doctrines derived from such a reading be applied to social, economic or political life. (p. 48)
This is in the hands of those who guard tradition and believe they alone know how to defend and protect the beliefs. Giddens (2003:48) warns about the danger of fundamentalism and its affects upon society.

\section{Balancing the effects of globalisation upon mission}

The challenges from globalisation require a thoughtful response from the church. Bulus Galadima suggests there are three ways of responding: (1) reject all aspects of globalisation and view them as secular trends; (2) embrace globalisation's 'relativism and pluralism' which leads to a 'fundamental transformation of religious beliefs'; or (3) wisely engage with the challenges presented by globalisation yet be informed by biblical truths that involve 'tact, creativity, and especially the enablement of the Holy Spirit' (Tiplady 2003:201).

A noticeable outcome of globalisation for the WGA is summed up in the popular slogan from the Lausanne Movement that mission is from 'everyone to everywhere.' This describes the Bible translation movement today, exemplified by the composition of the WGA, which has over 110 organisations from Europe, the Americas, the Pacific Islands, Asia and Africa. Even the name of the WGA itself reflects this change - moving from the terminology of 'International' to that of 'Global'. This new emphasis is necessary because the WGA has recognised the importance and influence of the missio Dei in the WGA's global perspective.

In the context of the WGA, the term 'Global Alliance' signifies a desire to bring various and multiple partners to the table for creative, collaborative thinking, working and problem solving. The WGA was not created to prescribe issues and strategies for others, nor is it a primarily Western organisation wishing to expand its territory worldwide. On the contrary, it is an alliance of like-minded, yet extremely diverse organisations and movements around the world, attempting to think and work under God's direction.

\section{Missiological interpretation of Vision 2025}

The WGA's aim is to see a Bible translated for each language group in the world that needs it. To accomplish this, the WGA does not operate in a vacuum. It is positively or adversely affected by trends including the church, the world and through influences of globalisation.

At WBTI's (since the name was not changed until 2011) Convention in 1999, delegates boldly set a new direction for the organisation in a resolution called 'Vision 2025', which reads:

Motivated by the pressing need for all peoples to have access to the Word of God in a language that speaks to their hearts, and reaffirming our historic values and our trust in God to accomplish the impossible, we embrace the vision that by the year 2025 a Bible translation project will be in progress for every 
people group that needs it. We acknowledge that this cannot be accomplished simply by our working harder or doing more of what we are now doing. It will require us to make significant changes in our attitudes and ways of working. Our desire is to build capacity for sustainable Bible translation programs and Scripture-use activities. Therefore, we urge each entity within our family of organisations to give priority to strengthening present partnerships, forming additional strategic partnerships, and working together to develop creative approaches appropriate to each context. To this end we commit ourselves to pray for the fulfilment of this vision, seeking God's guidance and obeying Him in whatever new directions He may lead. (WBTI 1999:5)

Thirteen years after pronouncing Vision 2025, the WGA continues in its commitment to the vision and, as it does so, it acknowledges and studies the various influences affecting its vision to ensure that it includes a solid missiological foundation.

The Vision 2025 statement touches on at least nine missiological implications: (1) an awareness of the 'pressing need' that still exists for Bible translation; (2) the adoption of a date as a means of motivating action; (3) a realisation that working harder is not what is required; (4) an acceptance that different attitudes and approaches are needed; (5) a focus on building capacity and sustainability; (6) a greater emphasis on partnering internally and externally; (7) an openness to new ways of working; (8) a recommitment to accomplishing the task; and (9) an intentional desire to be led by the Holy Spirit (WBTI 1999:5).

The concluding statement of Vision 2025 states that the organisation is 'seeking God's guidance and obeying Him in whatever new directions He may lead' (WBTI 1999:5). I suggest that this is at least a minimal acknowledgement of the missio Dei. When the vision was announced there was not a clear reference to the missio Dei in discussions leading up to the adoption of the resolution. Such missiological reinterpretation of the vision have started to take place in the last few years.

\section{Vision 2025 and the Great Commission}

The John 20:18-23 text of the Great Commission is relevant at this point. The Father sends Jesus and Jesus sends the church, empowered by the Spirit. The passage implies that any involvement in the missio Dei that is not Spirit-breathed will struggle for effectiveness. Whilst humans are involved in planning and action, it is primarily not about us, our activity or our initiative. Rather, it is God's invitation to his people to participate in his mission. Thus the onus of accomplishing Vision 2025 (or any vision related to the missio Dei) actually belongs to God.

The sense of urgency depicted in the resolution gives specific reference to the year 2025. This has a hint of Mark 16:15 in it ('the gospel will be preached to the nations and then the end will come'). However, this is only true if one uses the year 2025 as an eschatological reference point to Jesus' return and the ushering in of the end of the age as we now know it. This connection is a serious misreading of the Great Commission texts as well as a trivialisation of the complexity of Bible translation into the world's vernacular languages.

The opening statement of Vision 2025 acknowledges that it is 'our trust in God to accomplish the impossible,' which is at least a partial acknowledgement of the missio Dei. However, given the pragmatic history of the WGA, it is likely that the emphasis was intended, or at least interpreted, to be more about human involvement and responsibility than on the sending nature of the Triune God in mission, who invites people to join him. It is worth noting the changing understanding of the missio Dei within various parts of the church and how this might influence a missiological reinterpretation of Vision 2025.

Each of these cases justifies a missiological premise to the statement in the Vision 2025 resolution: 'a Bible translation project will be in progress for every people group that needs it' (WBTI 1999:5). This caveat 'that needs it' depicts the marginalisation and poverty that often exists amongst minority groups because of their lack of access to other major languages, higher levels of education, and so on. Nevertheless, the Triune God places no prohibitions on making his scriptures available beyond the original languages in which they were recorded. Therefore, Christians have the responsibility of ensuring that effective Bible translations (of the kind Nida had in mind) are made available to every people group that still needs them.

\section{Vision 2025 and the global growth of the church}

When one looks back to the composition of the WBTI in 1999 (when Vision 2025 was adopted), it was still a Western mission agency (with a smaller component of non-Western nations) contributing their resources to Bible translation. By 2012 this had changed significantly, to the extent that $70 \%$ of the 110 organisations that make up WGA are from the global South and East. However, the question remains about what kind of role the church in Western nations will play in developing strategies associated with Vision 2025. Balance will be required, with dialogue from the global South and East, so that their perspectives will have a continuing role in realising the vision.

At this writing, it is 13 years since the inception of Vision 2025 and over 70 years since the formation of the WBT. As the WGA has become more global in its focus and composition, its leaders have increasingly realised that this North American interpretation and implementation of the Great Commission is not completely accurate or helpful. For example, Vision 2025 acknowledges that working harder (in the sense of a Western Protestant work ethic) or 'doing more of what we are now doing' (WBTI 1999:5) would not accomplish the Vision. Rather than relying on traditional methods, translation efforts have to be done differently in many areas of the world. 


\section{Influences on Vision 2025 from streams of the church The Roman Catholic Church}

The Second Vatican Council in 1962 revealed an opportunity for greater collaboration and partnership between the Roman Catholic Church and other streams of the worldwide church. It portrayed a new understanding of the origins of the church, that:

are inextricably linked to Jesus' gathering a community of followers who ... were empowered by his Spirit to continue in his mission to serve, proclaim, and realize [sic] the coming reign of God. (Gaillardetz 2006:149)

The Church acknowledged that there were parts of the body of Christ outside of the Church's structures.

This wider collaboration has included Bible agencies, as well as various organisations within the WGA that serve language communities that are primarily Roman Catholic. This is an encouraging trend, although it may still be met with some suspicion by some agencies within the WGA. However, returning to Wycliffe's roots, Townsend's early work in Guatemala (and later in Mexico) was predominantly in Roman Catholic territory. He believed that his organisation should place its emphasis on the Bible 'rather than on the various interpretations of it' and the members of his organisations 'did not represent any of the established ecclesiastical organisations' (Hibberd 2007:6). Even in the early years of Townsend's work in Mexico a representative of the National University in a public address summed up the attitude of Townsend's colleagues by noting that: 'These young people have brought a message that is far above Catholicism and far above Protestantism. It is a gospel of love and service' (Hibberd 2007:6).

\section{The ecumenical churches}

The World Council of Churches (WCC) expresses its understanding of the missio Dei as 'God's sending forth' which has been expanded 'to include the participation of the church in the divine mission' (Balia \& Kim 2010:23). Consequently, mission is reframed from being churchcentric to becoming theo-centric. This position is echoed in the opening of the Edinburgh 2010 Common Call where the church is described as a sign and symbol of the reign of God that is called 'to witness to Christ today by sharing in God's mission of love through the transforming power of the Holy Spirit' (Edinburgh 2010). The report of study group 1 states, 'the central foundation for mission is the nature of the triune God, and how God works in the world' (Kim \& Anderson 2011:119).

By sponsoring the Edinburgh Conference 2010, the WCC articulated mission as a response to the 'abolition of injustice and building of a renewed society' (Balia \& Kim 2010:35). This bodes well for the people groups in focus by Vision 2025 because many live in situations of marginalisation where even basic human rights are exploited or neglected. A
Christian response to such evil is needed and encouraged by the WCC as well as the WGA.

A major outcome of the Edinburgh Conference 2010 is an understanding of how God is a part of the missionary task. It is God who pursues partnership with his followers (who come from very different theological and social backgrounds) and it is to them he 'eventually entrusts the task of global mission' (Balia \& Kim 2010:136).

\section{The evangelical church}

The Lausanne Commitment of the evangelical movement mentions engaging with 'unreached people groups' through a focus on language, culture and Bible translation. This is acted out when 'the mission of God's people flows from our love for God and for all that God loves' (Birdsall \& Brown 2011:6). The provision of the translated scriptures in the form(s) that suit them best is important and can be demonstrated by the wider evangelical world's affirmation and participation in Vision 2025.

This brief overview shows how different parts of the church have been reviewing their interpretation of the missio Dei. This should in turn impact how the WGA interprets the eventual accomplishment of Vision 2025 within the context of the missio Dei. It has been noted that the primary factor is not and cannot be based on human endeavours alone. Rather, it is God through his missio Dei who invites our participation to help achieve the vision.

\section{Conclusion}

This research has briefly examined the WGA and its Vision 2025 through missiological-theological lenses. The historical influence from North American evangelical fervour has been noted. It is commendable that this influence in mission has given solid focus to the involvement of people in planning and action. However, this has often been done in ignorance to the missio Dei being about God and his initiative and activity. As Wright (2006:67) helpfully explains, 'mission is God's ... [and] the marvel is that [he] invites us to join in.' As the global church becomes firmly planted in the soil of the global South and East, it provides a moderating influence on mission agencies such as the WGA. Further work is needed before we see how this influence may provide a balancing approach to the WGA and others in the Bible translation movement.

Vision 2025 was adopted at a time when Western influence in mission leadership and strategy were at their peak. Today, however, the vision is taking effect in contexts where 'the predominance of one culture over others is no longer accepted, and where cultural polycentrism is a fact of our time' (Balia \& Kim 2010:255).

Some degree of caution is needed when analysing the progress of the WGA in Bible translation (in terms of languages entered, works started, New Testament or full Bibles translated, number of new literates, etc.). Statistical 
progress is encouraging to the participants as well as those who fund the ministry, but history shows that progress is always uncertain and at times can be an illusion. A metric the WGA should consider is the collaboration of churches and mission agencies towards communities without access to the Bible.

\section{Acknowledgements Authors' contributions}

This article was submitted by K.J.F. (University of Pretoria) and accepted as part of the requirements for the MA (Theology) degree in September 2012, the Department of Science of Religion and Missiology, Faculty of Theology, University of Pretoria, under the guidance of C.J.P.N. (University of Pretoria).

\section{Competing interests}

The authors declare that they have no financial or personal relationship(s) that may have inappropriately influenced them in writing this article.

\section{References}

Balia, D. \& Kim, K. (eds.), 2010, Edinburgh 2010 volume II: Witnessing to Christ today Regnum Books, Oxford.

Barrett, D., Johnson, T. \& Crossing, P., 2008, 'Missiometrics 2008: Reality checks for Christian world communions', International Bulletin of Missionary Research 32(1), 27-30.

Bediako, K., 2004, Jesus and the gospel in Africa: History and experience, Orbis Books, Maryknoll.

Birdsall, D. \& Brown, L., 2010, 'The Lausanne Commitment' (Third Lausanne Congress on World Evangelisation), in The Lausanne Movement, viewed 18 May 2012, from http://www.lausanne.org/ctcommitment

Bosch, D., 1991, Transforming mission: Paradigm shifts in the theology of mission, Orbis Books, Maryknoll.

Carey, W., 1792, 'Enquiry into the obligation of Christians to use means for the conversion of heathens', in William Carey University, viewed 09 September 2012, from http://www.wmcarey.edu/carey/enquiry/anenquiry.pdf

Commission of World Mission and Evangelism 2012, Together towards life: Mission and evangelism in changing landscapes, viewed 12 May 2012, from http:// www.oikoumene.org/en/resources/documents/wcc-commissions/missionand-evangelism/together-towards-life-mission-and-evangelism-in-changinglandscapes.htm

CWME see Commission of World Mission and Evangelism.

Edinburgh 2010, Common call, viewed 18 May 2012, from http://www.edinburgh2010. org/fileadmin/Edinburgh_2010_Common_Call_with_explanation.pdf

Gailey, C. \& Culbertson, H., 2007, Discovering missions, Beacon Hill Press, Kansas City.
Gaillardetz, R., 2006, The church in the making: Lumen Gentium, Christus Dominus, Orientalium Ecclesiarum, Paulist Press, Mahwah.

Giddens, A., 2003, Runaway world: How globalisation is reshaping our lives, Routledge, New York. PMCid:1480272

Harrison, K.D., 2007, When languages die, Oxford University Press, New York. http:// dx.doi.org/10.1093/acprof:0so/9780195181920.001.0001

Hibberd, C. (ed.), 2007, Quotable Uncle Cam, SIL International Townsend Archives, Waxhaw.

Hunt, R., 2010, The gospel among the nations: A documentary history of inculturation, Orbis Books, Maryknoll.

Jenkins, P., 2002, The next Christendom: The coming of global Christianity, Oxford University Press, New York. http://dx.doi.org/10.1093/0195146166.001.0001

Jenkins, P., 2006, The new faces of Christianity: Believing the Bible in the global south, Oxford University Press, New York.

Johnstone, P., 2011, The future of the global church: History, trends and possibilities, Authentic Media, Milton Keynes.

Kim, K. \& Anderson, A. (eds.), 2011, Edinburgh 2010: Mission today and tomorrow, Regnum, Oxford.

Klauber, M. \& Manetsch, S., 2008, The great commission: Evangelicals and the history of world missions, Broadman \& Holman, Nashville.

Marcos, F., 2000, The Septuagint in context: Introduction to the Greek version of the Bible, Society of Biblical Literature, Atlanta.

Newbigin, L., 1989, The gospel in a pluralist society, William B. Eeerdmans, Grand Rapids.

Peskett, H. \& Ramachandra, V., 2003, The message of mission, Inter-varsity Press, Nottingham. PMid:14656868

Sanneh, L., 1989, Translating the message: The missionary impact on culture, Orbis Books, Maryknoll.

Sanneh, L., 2003, Whose religion is Christianity? The gospel beyond the west, William B. Eerdmans, Grand Rapids.

Smalley, W., 1991, Translation as mission: Bible translation in the modern missionary movement, Mercer University Press, Macon.

Smith, D., 2003, Mission after Christendom, Darton, Longman \& Todd, London.

Stine, P., 2012, 'Eugene A. Nida: Theoretician of translation', International Bulletin of Missionary Research 36(1), 38-39.

Svelmoe, W., 2008, A new vision for missions. William Cameron Townsend, the Wycliffe Bible Translators, and the culture of early evangelical faith missions, The University of Alabama Press, Tuscaloosa.

Tennent, T., 2010, Invitation to world missions: A trinitarian missiology for the twentyfirst century, Kregel, Grand Rapids.

Terry, J., Smith, E. \& Anderson, J. (eds.), 1998, Missiology: An introduction to the foundations, history and strategies of world missions, Broadman \& Holman, Nashville.

Tiplady, R. (ed.), 2003, One world or many? The impact of globalisation on mission, William Carey Library, Pasadena.

Walls, A., 1996, The missionary movement in Christian history: studies in the transmission of faith, Orbis Books, Maryknoll.

Walls, A., 2002, 'Demographics, power and the gospel in the $21^{\text {st }}$ century', paper presented at the Wycliffe International Convention and the SIL International Conference, Waxhaw, 06 June 2001.

WBTI see Wycliffe Bible Translators International.

Wegner, P., 1999, The journey from texts to translations: The origin and development of the Bible, Baker Academic, Grand Rapids.

Wycliffe Bible Translators International (WBTI) 1999 'Extracts of 1999 WBTI Convention', unpublished internal document, Wycliffe International, Dallas.

Wright, C., 2006, The mission of God: Unlocking the Bible's grand narratives, IVP Academic, Downers Grove. 